\title{
Article \\ A Green Composite Based on Gelatin/Agarose/Zeolite as a Potential Scaffold for Tissue Engineering Applications
}

\author{
Mohamadreza Youssefi Azarfam ${ }^{1}$, Mojtaba Nasirinezhad ${ }^{2} \mathbb{D}$, Haleh Naeim ${ }^{3}$, Payam Zarrintaj ${ }^{4, *}$ and \\ Mohammadreza Saeb 5 (D) \\ 1 Department of Chemistry, Oklahoma State University, Stillwater, OK 74078, USA; azarfam@okstate.edu \\ 2 Department of Chemical Engineering, Urmia University of Technology, Urmia 419-57155, Iran; \\ mojtaba462@gmail.com \\ 3 Chemical Engineering Department, Faculty of Renewable Energies, Urmia University of Technology, \\ Urmia 419-57155, Iran; h.naeim85@gmail.com \\ 4 Department of Biomedical and Pharmaceutical Science, University of Montana, Missoula, MT 59812, USA \\ 5 CentraleSupélec, Université de Lorraine, LMOPS, F-57000 Metz, France; mrsaeb2008@gmail.com \\ * Correspondence: payam.zarrintaj@umt.edu
}

check for updates

Citation: Youssefi Azarfam, M.; Nasirinezhad, M.; Naeim, H.; Zarrintaj, P.; Saeb, M. A Green Composite Based on Gelatin/Agarose/Zeolite as a Potential Scaffold for Tissue Engineering Applications. J. Compos. Sci. 2021, 5, 125. https://doi.org/ $10.3390 /$ jcs5050125

Academic Editor:

Francesco Tornabene

Received: 14 April 2021

Accepted: 7 May 2021

Published: 9 May 2021

Publisher's Note: MDPI stays neutral with regard to jurisdictional claims in published maps and institutional affiliations.

Copyright: (c) 2021 by the authors. Licensee MDPI, Basel, Switzerland. This article is an open access article distributed under the terms and conditions of the Creative Commons Attribution (CC BY) license (https:/ / creativecommons.org/licenses/by/ $4.0 /)$.

\begin{abstract}
Designing a novel platform capable of providing a proper tissue regeneration environment is a key factor in tissue engineering. Herein, a green composite based on gelatin/agarose/zeolite with pomegranate peel extract was fabricated as an innovative platform for tissue engineering. Gelatin/agarose was loaded with pomegranate peel extract-loaded zeolite to evaluate its swelling behavior, porosity, release rate, and cell viability performance. The composite characteristics were evaluated using XRD and DSC. The hydrogel performance can be adjusted for the desired aim by zeolite content manipulation, such as controlled release. It was shown that the green nanocomposite exhibited proper cellular activity along with a controlled release rate. Moreover, the hydrogel composite's swelling ratio was decreased by adding zeolite. This study suggested a fully natural composite as a potential biomaterial for tissue engineering, which opens new ways to design versatile hydrogels for the regeneration of damaged tissues. The hydrogel performance can be adjusted specifically by zeolite content manipulation for controlled release.
\end{abstract}

Keywords: gelatin; zeolite; green composite; tissue engineering; wound healing; facial mask

\section{Introduction}

Tissue engineering, as a newly emerging field, has attracted significant attention for the regeneration of damaged tissues/organs. Different factors are centered on tissue engineering, including cells, biological factors, and scaffolds [1-3]. Scaffolds can be fabricated with different structures like hydrogels that provide a proper environment for cellular activities. Various therapeutic agents have been examined for enhanced regeneration in scaffold design with exceptional cellular performance; sometimes capable of reducing the inflammation and inhibiting bacterial infections [4-6]. A scaffold with robust properties is of priority because of possessing an adjustable character for the desired target. For example, adjusting the water-uptake performance of hydrogel composite facilitates the application of a designed scaffold for wound healing purposes $[7,8]$.

Polysaccharides have been widely utilized in tissue engineering to fabricate scaffolds. Gelatin, as one of the promising natural polymers, exhibits an acceptable performance for tissue regeneration. Gelatin has been vastly utilized for wound healing because of its proper biocompatibility, ECM-resemblance, and pain-relieving properties [9-11]. Agarose shows self-gelling behavior as the widely used member of the polysaccharide family. Hydrogel formation needs a crosslinking agent to form a 3D network [12-14]. Crosslinking agents are small molecules that usually cause toxicity in the system. Self-gelation property of the agarose allows for eliminating the need for crosslinking agents $[15,16]$. 
Therapeutic factors can be loaded within the scaffold to increase the regeneration performance. Pomegranate, Punica granatum L. (Lythraceae), and its peel and seed (after aril) are known as precious materials in the healthy bioactive compounds, exhibiting antioxidant properties $[17,18]$. This is probably the main reason they have conventionally been used for inflammation and depigmentation therapies since a long time ago. The main ingredients of the pomegranate being responsible for therapeutic performance are polyphenols, flavonoids, and tannins. Kanlayavattanakul et al. showed that Pomegranate Peel Extract has proper cellular antioxidant and proliferative activities [19]. Loading therapeutic agents within the hydrogel results in burst release. On the other hand, encapsulation of the therapeutic agent within a carrier can make it possible to control the release rate [20-22]. Zeolite can be utilized as a platform for the delivery of various types of therapeutic agents [23]. Zeolite is capable of enhancing cell attachment strength, and in particular, can act as a specific topology guide on the cellular activity to achieve desired goals, thanks to the high surface area and high-level protein adsorption capacity. Furthermore, it has been shown that the nanoporous structure regulates the function of cells by changing the conformation of the proteins involved in the cellular attachment or by changing the surface energy [24,25].

Designing a proper scaffold for tissue engineering necessitates the combination of various factors in order to achieve the desired target. In this work, pomegranate peel extract-loaded gelatin/agarose/zeolite hydrogel composite was synthesized and characterized which can be used potentially as a scaffold for skin regeneration and rejuvenation. Thermal behavior, swelling behavior, release pattern, water vapor transition rate, and the biocompatibility of the composite were investigated to have a better understanding of the composite in the clinical applications. It is believed that this approach paves the way to design a novel platform for tissue engineering, specifically for skin care products.

\section{Material and Methods}

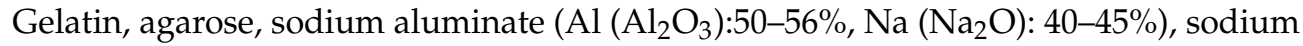
metasilicate nonahydrate, and sodium hydroxide were received from Sigma (St. Louis, MO, USA). Pomegranate peel extract was received from Chicest Polymeran Sanat (Urmia, Iran). All materials used as received without any purification.

\subsection{Green Composite Fabrication}

Zeolite was synthesized using the previously described method [26]. Briefly, $0.24 \mathrm{~g}$ sodium aluminate, $2.21 \mathrm{~g}$ of diatomite, and $1.6 \mathrm{~g}$ TPABr were mixed in a certain amount of deionized water. The mixture $\mathrm{pH}$ was adjusted at 10 using sodium hydroxide, followed by transferring into an autoclave for the hydrothermal process. The product was then filtered and washed using DI water several times and then dried at $100{ }^{\circ} \mathrm{C}$ overnight. Calcination was performed at $500{ }^{\circ} \mathrm{C}$ for $6 \mathrm{~h}$ to form Na-ZSM-5. In this study, no template was used to obtain the as-synthesized powder. At the final step, the obtained Na-ZSM-5 was treated by an ion exchange agent $\left(\mathrm{NH}_{4} \mathrm{NO}_{3}\right)$ for $6 \mathrm{~h}$ at $80{ }^{\circ} \mathrm{C}$ followed by filtering and washing with distilled water. The HZSM-5 powder was finally achieved via calcination at $500{ }^{\circ} \mathrm{C}$ for $4 \mathrm{~h}$. On the other hand, gelatin and agarose were dissolved in water and mixed with zeolite at ambient temperature for incubation. The resulting hydrogel was stored for further investigation.

\subsection{Mechanical Properties}

Cylinders with $10 \mathrm{~mm}$ diameter and $6 \mathrm{~mm}$ thickness were made from hydrogels to investigate the mechanical properties. Samples underwent uniaxial compression using a Santam-STM200 instrument with the load cell of $10 \mathrm{KN}$ and the strain rate of $1 \mathrm{~mm} \cdot \mathrm{min}^{-1}$ to determine samples' modulus.

\subsection{Swelling Behavior}

The swelling characteristic of hydrogel has a critical role in final applications. To evaluate the swelling performance, samples $\left(\mathrm{W}_{0}\right)$ were initially weighed and followed by 
immersion in water. At determined periods, the immersed sample $\left(\mathrm{W}_{\mathrm{t}}\right)$ was weighed to determine the swelling ratio $\left(S R=\left(\mathrm{W}_{\mathrm{t}}-\mathrm{W}_{0} / \mathrm{W}_{0}\right)\right)$.

\subsection{Porosity Evaluation}

The morphology of the selected hydrogel was assessed via scanning electron microscopy (SEM). The SEM images were taken from the fracture surfaces of the samples. Moreover, liquid displacement technique was utilized to understand the porosity of the composite. The freeze-dried hydrogel was soaked in ethanol for $3 \mathrm{~min}$. Then samples were taken out, and the sample porosity was calculated using Porosity $=\left(\mathrm{V}_{0}-\mathrm{V}_{2}\right) /\left(\mathrm{V}_{1}-\mathrm{V}_{2}\right)$ equation, where $V_{0}, V_{1}$, and $V_{2}$ are the initial volume of ethanol, the volume after the sample immersion, and the final volume without sample, respectively.

\subsection{Thermal Behavior}

Differential Scanning Calorimetry (DSC) technique (PerkinElmer 8000) was applied to monitor the changes in the heat flow of the sample vs. the temperature under nitrogen flow. Heating and cooling rates were $+10^{\circ} \mathrm{C} / \mathrm{min}$ and $-10^{\circ} \mathrm{C} / \mathrm{min}$, respectively.

\subsection{Release Behavior}

Hydrogel composite was mixed with the Pomegranate Peel Extract. Initially, Pomegranate Peel Extract (PX) was added to each sample's solution before gelation to study the release kinetics. The samples were soaked with the PBS at $37^{\circ} \mathrm{C}$ to mimic the biological environment. UV-Vis spectroscopy $(\lambda=472 \mathrm{~nm})$ was performed to assess the drug release values in PBS to investigate the release behavior. Various concentrations of PX were used to make standard solutions to graph the calibration curve. The absorbance of each sample was calculated from the Beer-Lambert law.

\subsection{Cellular Assessment}

3-(4,5-dimethylthiazol-2-yl)-2,5-diphenyltetrazolium bromide (MTT) assay was used for the cell viability test. Samples were sterilized and immersed in PBS overnight followed by soaking in Dulbecco's modified eagle medium (DMEM). Then, samples washed by PBS and fibroblast cells (L929 mouse fibroblast cell line) cultured on the samples in a 48-well culture plate and incubated at $37^{\circ} \mathrm{C}$ with $5 \% \mathrm{CO}_{2}$. After that, DMEM was rinsed, and the MTT solution was poured on the sample to evaluate the sample biocompatibility. After a certain time, using DMSO dissolved the formazan released from cells, and the absorbance at a certain wavelength was read using an ELIZA reader.

\subsection{Statistical Analysis}

Data were shown as mean \pm standard deviation and evaluated using Student's $t$-test. $p$ value $<0.05$ was believed significant.

\section{Result and Discussion}

In this work, the hydrogel composite was fabricated based on agarose self-gelling properties. 3D network formation of hydrogel formation is a challenging issue because of using the crosslinking agent. Crosslinking agents form a 3D network of hydrogel and provide mechanical stability, but they typically show toxicity. Self-gelling hydrogels such as agarose forms 3D network without crosslinking thanks to the hydrogen bond, electrostatic interaction, and helical structure formation (Figure 1). Self-gelling material like agarose can be used with other polysaccharides like alginate to reduce the cross-linking agent usages [27]. 


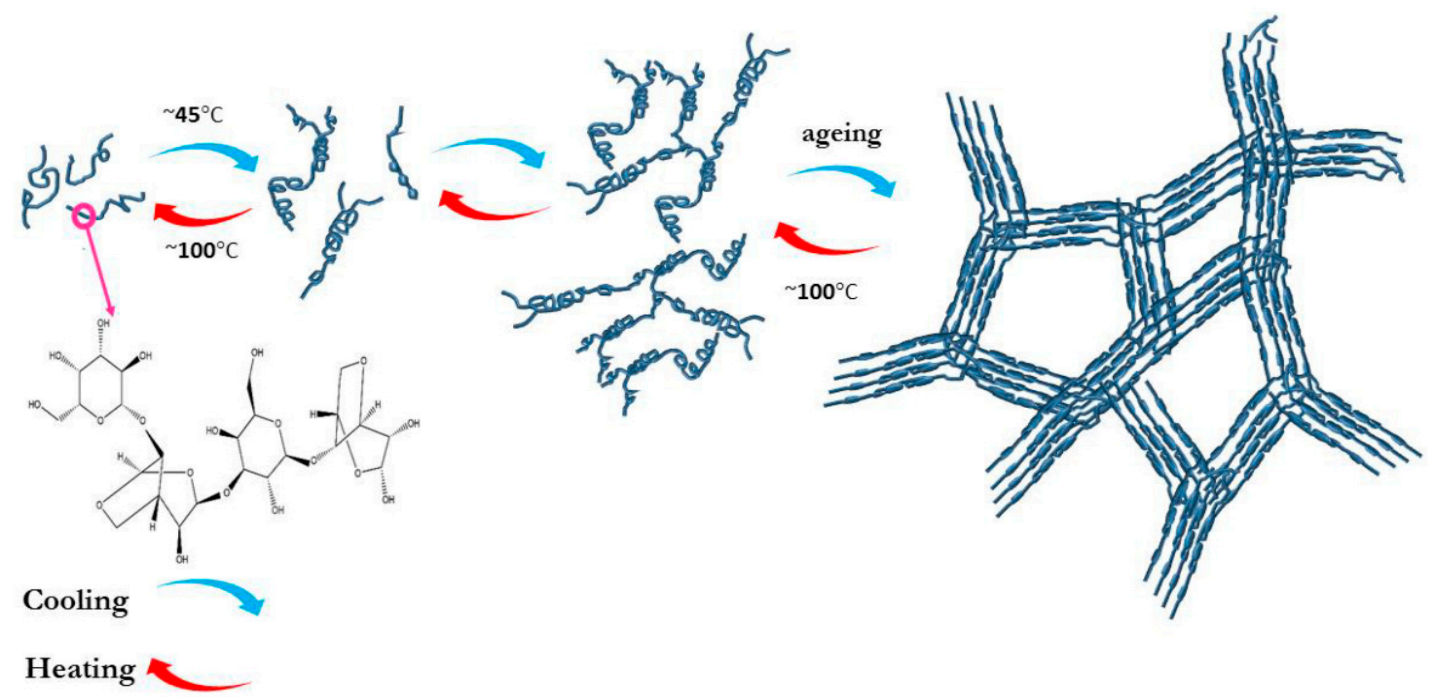

Figure 1. Agarose Gelation Mechanism: agarose chains lean to form helical structure and gel because of the hydrogen bonding and electrostatic interaction.

Different ratios of agarose and gelatin were selected to evaluate the mechanical and thermal behaviors of the composites. It was found that the addition of more gelatin resulted in network failure and reduced the composite mechanical properties. The Modulus of the composites is shown in Table 1. Agarose shows a self-gelling behavior by forming networks through hydrogen bonds, which is illustrated in Figure 1. On the other hand, DSC thermograms showed that the addition of gelatin to the agarose decreases the melting point of the composite, indicating the weakness of the gel network (Figure 2). In other words, gelatin addition to the agarose network hampers the network formation and weakens the gel network strength, which results in the reduction of the melting point of the gel along with the reduction in the mechanical strength. The agarose melting point is around $100{ }^{\circ} \mathrm{C}$; however, adding gelatin reduced the composite gelation point to around $90{ }^{\circ} \mathrm{C}$. As observed in all of the peaks, the samples show one broad melting peak, indicating adequate miscibility of the agarose and gelatin. Also, as the SEM image (Figure 3) showed a uniform microstructure without any phase separation. It should be noted that such uniform composites are highly desirable in tissue engineering.

Gelatin is the denatured form of collagen, showing high biocompatibility. Selecting a hydrogel for tissue engineering applications requires maintaining a subtle balance between simplicity and complexity. Along with the biocompatibility and cell affinity, mechanical properties should be considered. Also, one should consider that the stiffness of the hydrogel might affect cell activities. Rowlands et al. showed that the cells could proliferate and spread easily on the hydrogel with a stiffness of around $25 \mathrm{kPa}$ [28]. For this reason, the AGel-2 sample was selected for further investigations. The next step was the addition of zeolite to the composites. The strong diffraction peaks in the XRD pattern (Figure 4) of zeolite show the creation of crystalline phases. The main peaks are observed at $23.21^{\circ}$, and $34.02^{\circ}$.

Table 1. Green composite modulus.

\begin{tabular}{ccc}
\hline Sample & Ratio (Agarose/Gelatin) & Modulus (kPa) \\
\hline Agarose & - & 30 \\
AGel-1 & $(90 / 10)$ & 27 \\
AGel-2 & $(80 / 20)$ & 25 \\
AGel-3 & $(70 / 30)$ & 20 \\
\hline
\end{tabular}




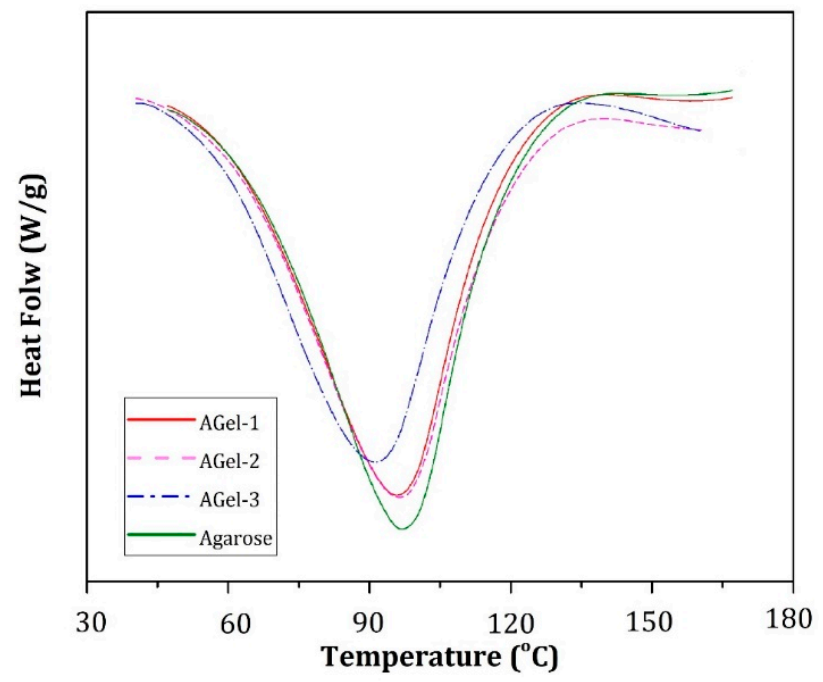

Figure 2. Overlaid differential scanning calorimetry (DSC) thermograms of the Agarose and AGel-1, AGel-2 and AGel-3 composites.

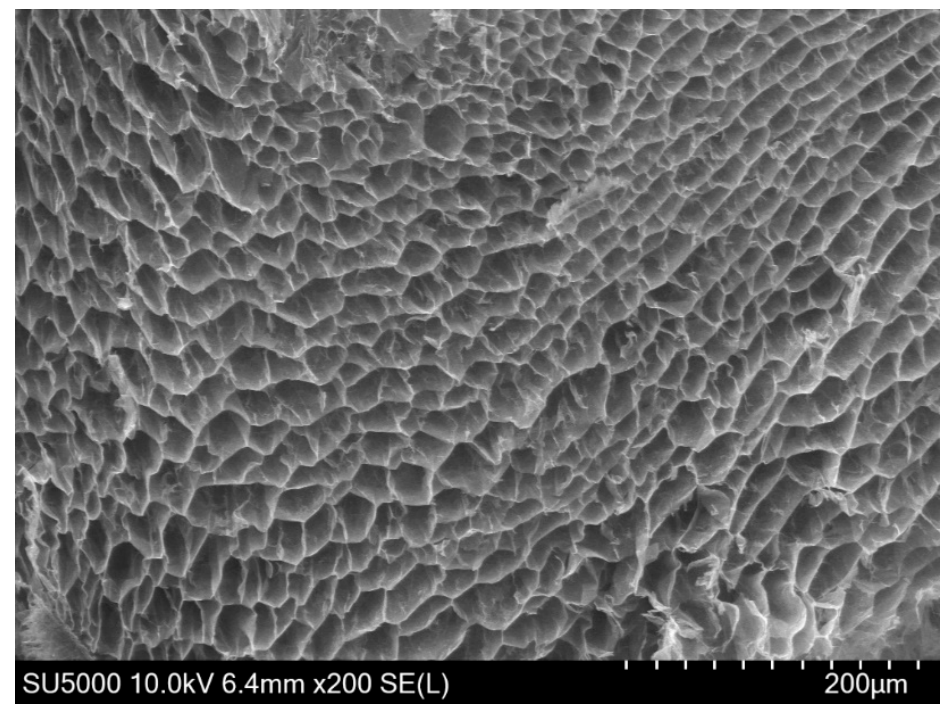

Figure 3. SEM image of the hydrogel porosity taken from the fracture surface of the sample.

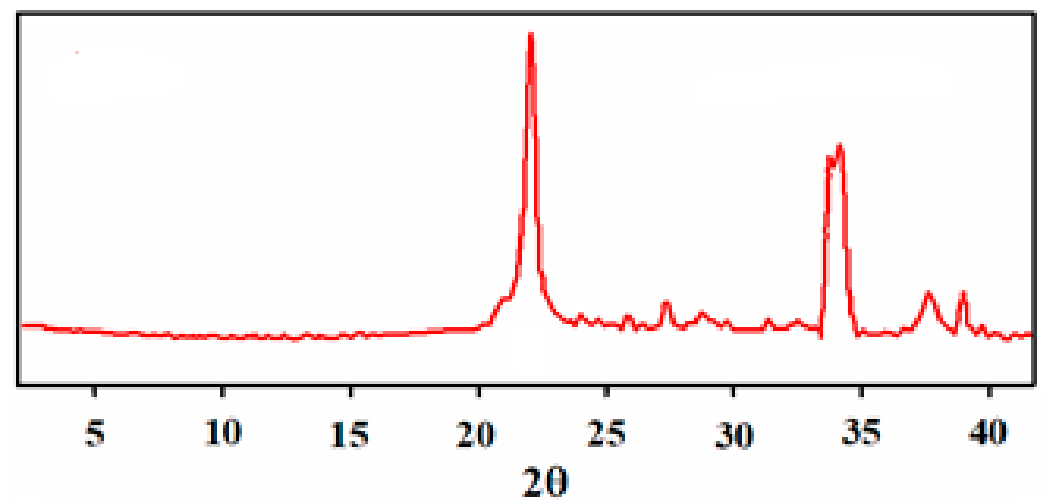

Figure 4. XRD pattern of the zeolite.

By variation of the zeolite content, hydrogel composite's swelling ratio can be adjusted to an optimum value, which is an important fact in tissue engineering applications such as wound healing systems. A moist milieu improves the healing procedure of the wound by controlling hydration/dehydration, increasing angiogenesis, and synthesizing collage 
which decreases the pain along with improving the wound aesthetics. The infection risk of the moist environment is lower than conventional dry trophies [29]. To this aim, the hydrogel composite swelling behavior was evaluated with different content of the zeolite. The swelling ratio of the hydrogel composite is illustrated in Figure 5. The it is evident that introducing zeolite into the hydrogel composites improves the hydrogel composite integrity and decreases the swelling ratio.

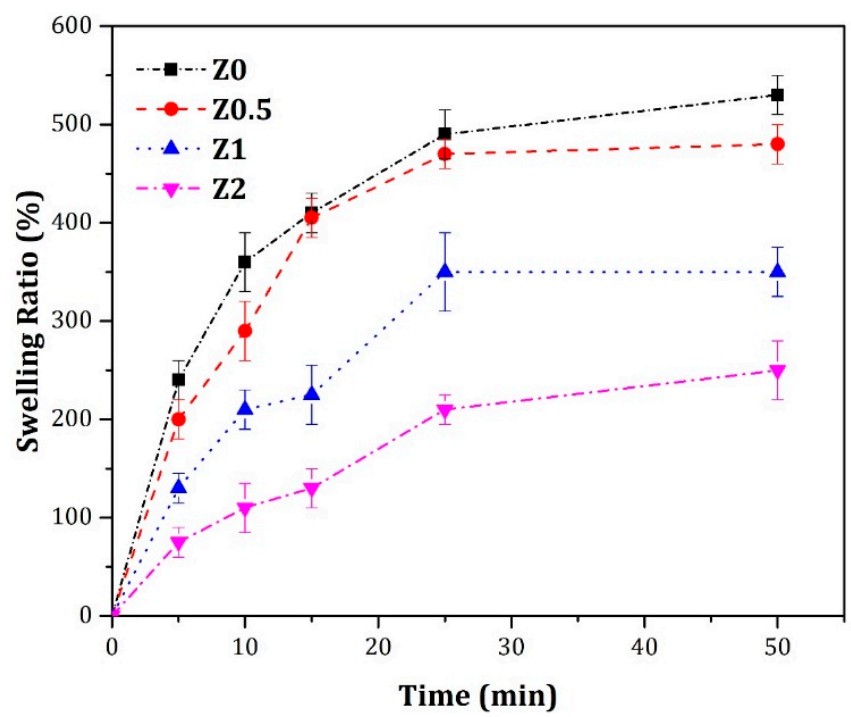

Figure 5. Swelling ratio of the hydrogel composite with different content of the zeolite.

Porosity has a significant role in tissue engineering. The function of seeded cells highly depends on the porosity, which has a dominant role in nutrient/waste exchange and oxygen diffusion. Moreover, porosity affects cellular activities, including cellular adhesion and interaction. The porosity of samples was measured by the liquid displacement method, and found to be about $87 \%$, which is suitable for tissue engineering applications [30].

Cell viability on hydrogel composites was evaluated using the MTT method. Supporting the cell growth is the most important factor of the scaffold, which causes the proper regeneration. Figure 6 represents the MTT results during 5 days. The graph indicates that on the first day, the samples' proliferation is roughly similar $(p>0.05)$. After incubation for 3 and 5 days, cells exhibited better proliferation in the samples compared to tissue culture polystyrene, suggesting that the hydrogel composites provide a desirable environment for the cell proliferation (Figure 6). Zeolite presence in the composites causes the creation of anchors on the scaffold and increases the focal adhesion [31,32]. Figure 6 reveals that the sample with $0.5 \%$ zeolite has a slightly higher cell proliferation compared to other samples. Hence, it can be inferred that the zeolite addition up to $2 \%$ does not affect the hydrogel biocompatibility adversely, and the synthesized hydrogel composites show adequate biocompatibility and cell proliferation. Zeolite addition can be used to adjust the therapeutic agent release to achieve the controlled and sustained release. In this regards, PX release was assed using different percentage of the zeolite in hydrogel.

PX shows cutaneous advantages and is used for treating skin disease such as hyperpigmentation. It is reported that PX exhibited proper cellular biocompatibility in both form of the serum and mask [19]. PX assists the wound healing process through promoting hemostasis, immunomodulatory, antibacterial, anti-atherosclerotic, and anti-oxidative activity, as well as killing parasites [33]. In this work, the release kinetics of the PX was studied to determine its release behavior using different content of the zeolite (Figure 7). It can be deduced that the zeolite addition affects the release behavior, and the zeolite content can be adjusted based on the desired release rate. 


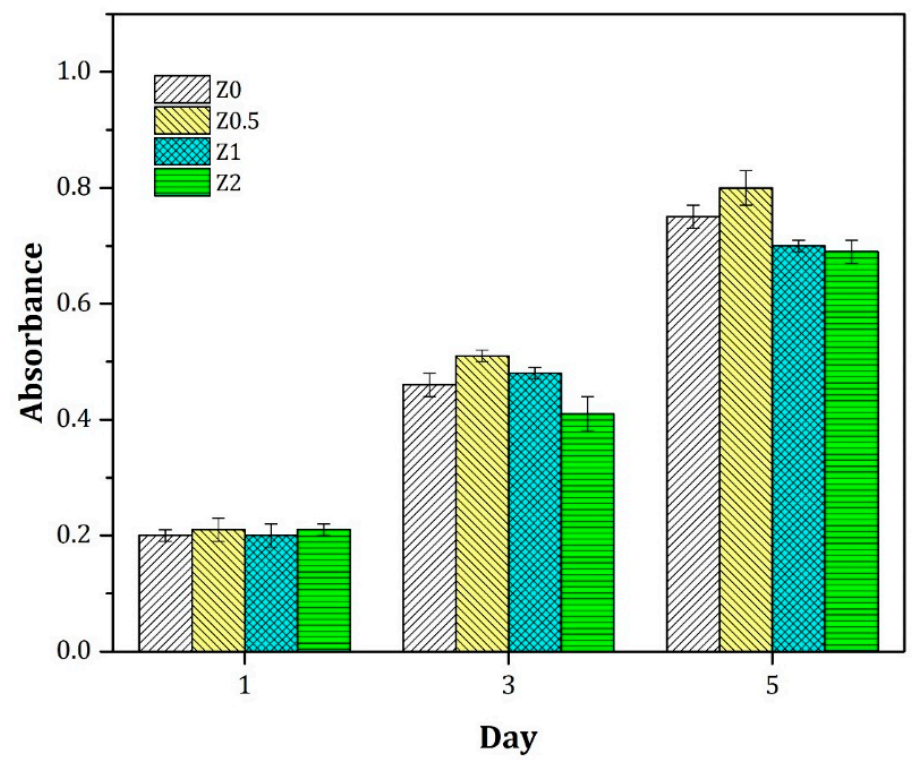

Figure 6. Cell viability of fibroblast cell on hydrogel composite at 1, 3 and 5 days.

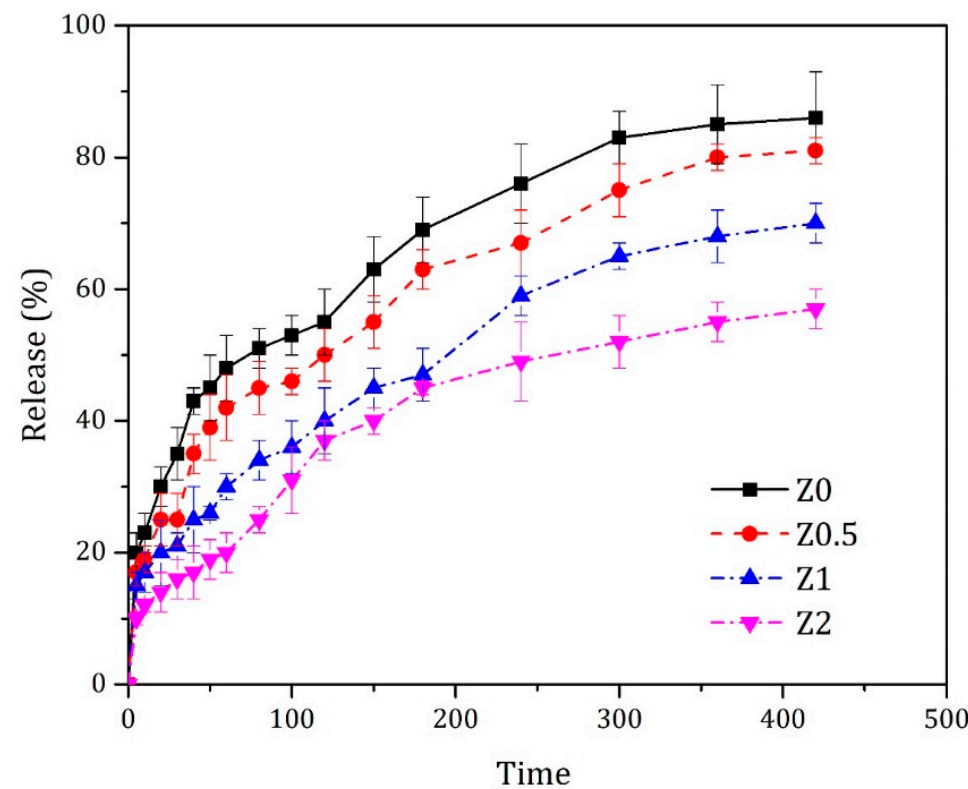

Figure 7. PX release rate from hydrogel composite in different percentage of zeolite.

\section{Conclusions}

In this study, hydrogel composites based on gelatin/agarose/zeolite were fabricated to evaluate their properties as a scaffold for tissue engineering. The optimum gelatin/agarose composition was selected, showing the proper mechanical properties along with acceptable biocompatibility. The hydrogel showed acceptable mechanical stability and porosity for tissue engineering. By adding the zeolite, composite properties such as swelling and drug release rate can be adjusted depending on the application. Zeolite presence within the hydrogel reduces the swelling ratio, as well as the release rate of therapeutic agent, wherein can be used to achieve the desired drug release rate. Our findings showed that such hydrogel composites could be suitable candidates for tissue engineering applications.

Author Contributions: Conceptualization, M.Y.A., P.Z. and M.S.; methodology, M.Y.A., M.N. and H.N.; software, M.Y.A.; validation, P.Z., M.S. and M.N.; formal analysis, M.Y.A., H.N., M.N.; investigation, M.Y.A., H.N.; resources, M.S.; data curation, M.Y.A., M.N., M.S.; writing-original draft preparation, M.Y.A., P.Z.; writing—review and editing, M.Y.A., M.N., M.S.; visualization, M.N., P.Z.; 
supervision M.N., P.Z., M.S.; project administration, P.Z., M.S.; funding acquisition, M.N., P.Z. and M.S. All authors have read and agreed to the published version of the manuscript.

Funding: This research received no external funding.

Conflicts of Interest: The authors declare no conflict of interest.

\section{References}

1. Bakhshandeh, B.; Zarrintaj, P.; Oftadeh, M.O.; Keramati, F.; Fouladiha, H.; Sohrabi-Jahromi, S.; Ziraksaz, Z. Tissue engineering; strategies, tissues, and biomaterials. Biotechnol. Genet. Eng. Rev. 2017, 33, 144-172. [CrossRef]

2. Jennings, J.A.; Wells, C.M.; McGraw, G.S.; Pulgarin, D.A.V.; Whitaker, M.D.; Pruitt, R.L.; Bumgardner, J.D. Chitosan coatings to control release and target tissues for therapeutic delivery. Ther. Deliv. 2015, 6, 855-871. [CrossRef]

3. Aghazadeh, H.; Yazdi, M.K.; Kolahi, A.; Yekani, M.; Zarrintaj, P.; Ramsey, J.D.; Ganjali, M.R.; Stadler, F.J.; Saeb, M.R.; Mozafari, M. Synthesis, characterization and performance enhancement of dry polyaniline-coated neuroelectrodes for electroencephalography measurement. Curr. Appl. Phys. 2021, 27, 43-50. [CrossRef]

4. Wells, C.M.; Beenken, K.E.; Smeltzer, M.S.; Courtney, H.S.; Jennings, J.A.; Haggard, W.O. Ciprofloxacin and Rifampin Dual Antibiotic-Loaded Biopolymer Chitosan Sponge for Bacterial Inhibition. Mil. Med. 2018, 183, 433-444. [CrossRef]

5. Jennings, J.A.; Pulgarin, D.A.V.; Kunwar, D.L.; Babu, J.; Mishra, S.; Bumgardner, J. Bacterial inhibition by chitosan coatings loaded with silver-decorated calcium phosphate microspheres. Thin Solid Films 2015, 596, 83-86. [CrossRef]

6. Erfani, A.; Hanna, A.; Zarrintaj, P.; Manouchehri, S.; Weigandt, K.; Aichele, C.P.; Ramsey, J.D. Biodegradable zwitterionic poly(carboxybetaine) microgel for sustained delivery of antibodies with extended stability and preserved function. Soft Matter 2021. [CrossRef]

7. Zarrintaj, P.; Yazdi, M.K.; Azarfam, M.Y.; Zare, M.; Ramsey, J.; Seidi, F.; Saeb, M.R.; Ramakrishna, S.; Mozafari, M. Injectable Cell-laden Hydrogels for Tissue Engineering: Recent Advances and Future Opportunities. Tissue Eng. Part A 2021. [CrossRef] [PubMed]

8. Nourbakhsh, M.; Zarrintaj, P.; Jafari, S.H.; Hosseini, S.M.; Aliakbari, S.; Pourbadie, H.G.; Naderi, N.; Zibaii, M.I.; Gholizadeh, S.S.; Ramsey, J.D.; et al. Fabricating an electroactive injectable hydrogel based on pluronic-chitosan/aniline-pentamer containing angiogenic factor for functional repair of the hippocampus ischemia rat model. Mater. Sci. Eng. C 2020, 117, 111328. [CrossRef]

9. Mohebbi, S.; Nezhad, M.N.; Zarrintaj, P.; Jafari, S.H.; Gholizadeh, S.S.; Saeb, M.R.; Mozafari, M. Chitosan in Biomedical Engineering: A Critical Review. Curr. Stem Cell Res. Ther. 2019, 14, 93-116. [CrossRef]

10. Zugravu, M.V.; Smith, R.A.; Reves, B.T.; Jennings, J.A.; Cooper, J.O.; Haggard, W.O.; Bumgardner, J.D. Physical properties and in vitro evaluation of collagen-chitosan-calcium phosphate microparticle-based scaffolds for bone tissue regeneration. J. Biomater. Appl. 2013, 28, 566-579. [CrossRef] [PubMed]

11. Zarrintaj, P.; Zangene, E.; Manouchehri, S.; Amirabad, L.M.; Baheiraei, N.; Hadjighasem, M.R.; Farokhi, M.; Ganjali, M.R.; Walker, B.W.; Saeb, M.R.; et al. Conductive biomaterials as nerve conduits: Recent advances and future challenges. Appl. Mater. Today 2020, 20, 100784. [CrossRef]

12. Yazdi, M.K.; Taghizadeh, A.; Taghizadeh, M.; Stadler, F.J.; Farokhi, M.; Mottaghitalab, F.; Zarrintaj, P.; Ramsey, J.D.; Seidi, F.; Saeb, M.R.; et al. Agarose-based biomaterials for advanced drug delivery. J. Control. Release 2020, 326, 523-543. [CrossRef]

13. Erfani, A.; Zarrintaj, P.; Seaberg, J.; Ramsey, J.D.; Aichele, C.P. Zwitterionic poly(carboxybetaine) microgels for enzyme (chymotrypsin) covalent immobilization with extended stability and activity. J. Appl. Polym. Sci. 2021, 138, 50545. [CrossRef]

14. Nilforoushzadeh, M.A.; Yazdi, M.K.; Ghavami, S.B.; Farokhimanesh, S.; Amirabad, L.M.; Zarrintaj, P.; Saeb, M.R.; Hamblin, M.R.; Zare, M.; Mozafari, M. Mesenchymal Stem Cell Spheroids Embedded in an Injectable Thermosensitive Hydrogel: An In Situ Drug Formation Platform for Accelerated Wound Healing. ACS Biomater. Sci. Eng. 2020, 6, 5096-5109. [CrossRef] [PubMed]

15. Salati, M.A.; Khazai, J.; Tahmuri, A.M.; Samadi, A.; Taghizadeh, A.; Taghizadeh, M.; Zarrintaj, P.; Ramsey, J.D.; Habibzadeh, S.; Seidi, F.; et al. Agarose-Based Biomaterials: Opportunities and Challenges in Cartilage Tissue Engineering. Polymers 2020, 12, 1150. [CrossRef] [PubMed]

16. Zarrintaj, P.; Manouchehri, S.; Ahmadi, Z.; Saeb, M.R.; Urbanska, A.M.; Kaplan, D.L.; Mozafari, M. Agarose-based biomaterials for tissue engineering. Carbohydr. Polym. 2018, 187, 66-84. [CrossRef]

17. Fleck, A.; Cabral, P.F.G.; Vieira, F.F.M.; Pinheiro, D.A.; Pereira, C.R.; Santos, W.C.; Machado, T.B. Punica granatum L. Hydrogel for Wound Care Treatment: From Case Study to Phytomedicine Standardization. Molecules 2016, 21, 1059. [CrossRef]

18. Marchiori, M.C.L.; Rigon, C.; Camponogara, C.; Oliveira, S.M.; Cruz, L. Hydrogel containing silibinin-loaded pomegranate oil based nanocapsules exhibits anti-inflammatory effects on skin damage UVB radiation-induced in mice. J. Photochem. Photobiol. $B$ Biol. 2017, 170, 25-32. [CrossRef] [PubMed]

19. Kanlayavattanakul, M.; Chongnativisit, W.; Chaikul, P.; Lourith, N. Phenolic-rich Pomegranate Peel Extract: In Vitro, Cellular, and In Vivo Activities for Skin Hyperpigmentation Treatment. Planta Medica 2020, 86, 749-759. [CrossRef]

20. Babanejad, N.; Nabid, M.R.; Farhadian, A.; Dorkoosh, F.; Zarrintaj, P.; Saeb, M.R.; Mozafari, M. Sustained delivery of olanzapine from sunflower oil-based polyol-urethane nanoparticles synthesised through a cyclic carbonate ring-opening reaction. IET Nanobiotechnol. 2019, 13, 703-711. [CrossRef]

21. Zarrintaj, P.; Yazdi, M.K.; Bagheri, B.; Kim, Y.C.; Ramsey, J.D.; Saeb, M.R. Block copolymers for nanoscale drug and gene delivery. In Nanoengineered Biomaterials for Advanced Drug Delivery; Elsevier BV: Amsterdam, Netherlands, 2020; pp. 181-200. 
22. Arkaban, H.; Ebrahimi, A.K.; Yarahmadi, A.; Zarrintajj, P.; Barani, M. Development of a multifunctional system based on $\mathrm{CoFe}_{2} \mathrm{O}_{4} @$ polyacrylic acid NPs conjugated to folic acid and loaded with doxorubicin for cancer theranostics. Nanotechnology 2021. [CrossRef] [PubMed]

23. Servatan, M.; Zarrintaj, P.; Mahmodi, G.; Kim, S.-J.; Ganjali, M.R.; Saeb, M.R.; Mozafari, M. Zeolites in drug delivery: Progress, challenges and opportunities. Drug Discov. Today 2020, 25, 642-656. [CrossRef]

24. Zarrintaj, P.; Mahmodi, G.; Manouchehri, S.; Mashhadzadeh, A.H.; Khodadadi, M.; Servatan, M.; Ganjali, M.R.; Azambre, B.; Kim, S.; Ramsey, J.D.; et al. Zeolite in tissue engineering: Opportunities and challenges. Mol. Carcinog. 2020, 1, 5-34. [CrossRef]

25. Yazdi, M.K.; Zarrintaj, P.; Hosseiniamoli, H.; Mashhadzadeh, A.H.; Saeb, M.R.; Ramsey, J.D.; Ganjali, M.R.; Mozafari, M. Zeolites for theranostic applications. J. Mater. Chem. B 2020, 8, 5992-6012. [CrossRef] [PubMed]

26. Servatan, M.; Ghadiri, M.; Yazdi, M.K.; Jouyandeh, M.; Mahmodi, G.; Samadi, A.; Zarrintaj, P.; Habibzadeh, S.; Ganjali, M.R.; Saeb, M.R. Synthesis of Cost-Effective Hierarchical MFI-Type Mesoporous Zeolite: Introducing Diatomite as Silica Source. Silicon 2020, 1-12. [CrossRef]

27. Zarrintaj, P.; Bakhshandeh, B.; Rezaeian, I.; Heshmatian, B.; Ganjali, M.R. A Novel Electroactive Agarose-Aniline Pentamer Platform as a Potential Candidate for Neural Tissue Engineering. Sci. Rep. 2017, 7, 1-12. [CrossRef] [PubMed]

28. Rowlands, A.S.; George, P.A.; Cooper-White, J.J. Directing osteogenic and myogenic differentiation of MSCs: Interplay of stiffness and adhesive ligand presentation. Am. J. Physiol. Physiol. 2008, 295, C1037-C1044. [CrossRef] [PubMed]

29. Junker, J.P.; Kamel, R.A.; Caterson, E.; Eriksson, E. Clinical Impact Upon Wound Healing and Inflammation in Moist, Wet, and Dry Environments. Adv. Wound Care 2013, 2, 348-356. [CrossRef]

30. Bružauskaitè, I.; Bironaitè, D.; Bagdonas, E.; Bernotienè, E. Scaffolds and cells for tissue regeneration: Different scaffold pore sizes-different cell effects. Cytotechnology 2016, 68, 355-369. [CrossRef]

31. Tavolaro, P.; Martino, G.; Andò, S.; Tavolaro, A. Fabrication and evaluation of novel zeolite membranes to control the neoplastic activity and anti-tumoral drug treatments in human breast cancer cells. Part 1: Synthesis and characterization of Pure Zeolite Membranes and Mixed Matrix Membranes for adhesion and growth of cancer cells. Mater. Sci. Eng. C 2016, 69, 894-904. [CrossRef]

32. Tavolaro, P.; Catalano, S.; Martino, G.; Tavolaro, A. Zeolite inorganic scaffolds for novel biomedical application: Effect of physicochemical characteristic of zeolite membranes on cell adhesion and viability. Appl. Surf. Sci. 2016, 380, 135-140. [CrossRef]

33. Yan, H.; Peng, K.-J.; Wang, Q.-L.; Gu, Z.-Y.; Lu, Y.-Q.; Zhao, J.; Xu, F.; Liu, Y.-L.; Tang, Y.; Deng, F.-M.; et al. Effect of pomegranate peel polyphenol gel on cutaneous wound healing in alloxan-induced diabetic rats. Chin. Med. J. 2013, 126, 1700-1706. [PubMed] 